\title{
A Survey on the Current State of Lighting Design Education in Interior Design Programs in Turkey and Northern Cyprus
}

\author{
Türkiye ve Kuzey Kıbrıs'ta Bulunan İç Mimarlık Programlarındaki \\ Aydınlatma Eğitiminin Güncel Durumu Üzerine Bir Araştırma
}

\author{
Sezin Hatice TANRIÖVER, Kenan Eren ŞANSAL
}

This paper presents the results of a 2-phase study conducted in order to understand the current state of lighting design education in interior design departments in Turkey and Northern Cyprus, and to report whether or not there is a need to adopt a different approach to lighting design education. In the first phase, information about undergraduate and graduate courses offered specifically for lighting design and those that include lighting design in addition to other building sciences, such as acoustics and HVAC, was gathered. In the second phase, department chairs were contacted and asked to comment on their approach to lighting design education. The results of the first phase revealed the lack of compulsory courses in the subject, an inadequacy of practical course hours, variations in the weekly hours of courses, differences in the credit values, and a scarcity of graduate programs with courses in lighting design. The results of the second phase, obtained in the statements of respondents, pointed out issues to be addressed regarding the lack of facilities and equipment for practice, the number of compulsory courses, and limited collaboration between industry and universities. In the light of our findings, it is thought that it may be necessary to adopt a different approach to lighting design education in the departments of interior design.

Keywords: Interior design education; lighting design; lighting design education.

Öz

Bu makale, Türkiye ve Kuzey Kıbrıs'taki içmimarlık bölümlerinde verilmekte olan aydınlatma tasarımı eğitiminin mevcut durumunu ve aydınlatma tasarımı eğitiminde farklı bir yaklaşımın benimsenmesinin gerekli olup olmadığını anlamak için gerçekleştirilen iki aşamalı bir çalışmanın sonuçlarını sunar. Illk aşamada, aydınlatma tasarımı için verilmekte olan lisans ve lisansüstü özel dersler ile bu konuyu içermekte olan ilgili diğer genel dersler hakkında bilgi toplanmıştır. İinci aşamada, bölüm başkanları ile temas kurularak, aydınlatma tasarımı eğitimine yaklaşımları ile ilgili olarak bilgi talep edilmiştir. Illk aşamanın sonuçları, konu ile ilgili zorunlu derslerin sayısının az olduğunu, uygulama yapılan ders saatlerinin yetersizliğini, haftalık ders saatlerindeki farklııkları, ders kredilerindeki farklııkları ve aydınlatma tasarımı ile ilgili derslerin lisansüstü programlarında çok fazla yer bulamadığını ortaya koymuştur. Katılımcıların geribildirimleri ile elde edilen ikinci aşamanın sonuçları, tesis ve ekipman eksiklikleri, zorunlu derslerin az olması ve eğitim kurumları ile sanayi arasındaki sınırlı işbirliği ile ilgili sorunların giderilmesi gereğini işaret etmektedir. Bu bulguların ışı̆̆ında, iç mekan tasarımı bölümlerinde verilmekte olan aydınlatma tasarımı eğitimi için farklı bir yaklaşımın benimsenmesinin gerekli olabileceği düşünülmektedir.

Anahtar sözcükler: İcmimarlık eğitimi; aydınlatma tasarımı; aydınlatma tasarımı eğitimi.

Department of Interior Architecture and Environmental Design, Bahçeşehir University Faculty of Architecture and Design, İstanbul, Turkey

Article arrival date: November 17, 2016 - Accepted for publication: September 21, 2017

Correspondence: Sezin Hatice TANRIÖVER. e-mail: sezin.tanriover@gmail.com

○ 2017 Yıldız Teknik Üniversitesi Mimarlık Fakültesi - ๑ 2017 Yıldız Technical University, Faculty of Architecture 


\section{Introduction}

Light is not just a kind of electromagnetic radiation that has been emitted in the visible wavelength range between 380 and $780 \mathrm{~nm}$. If it is designed thoughtfully, light not only allows us to see our task with comfort and ease but also contributes to the beauty of architecture by revealing forms, rhythms, colours and textures. ${ }^{1}$ Apart from enabling vision and affecting our perception of spaces and its elements, light also has implications on human health. For example, it has been consistently and repeatedly demonstrated that exposure to light can reduce circadian misalignment and, thus, be an effective treatment for a number of common sleep disorders and seasonally affective disorder, a subtype of major depression. ${ }^{2}$ Given these effects and the fact that we spend the majority of our time in buildings, ${ }^{3}$ it seems reasonable to suggest that our general well-being and quality of life is highly contingent upon the successful incorporation of natural light and artificial lighting systems into the built environment. If we accept that good lighting is a necessity rather than a luxury, then the question arises as to how it can be achieved. It is obvious that providing sufficient knowledge about light and its use in interior design education is instrumental in attaining this goal.

Universities having interior design departments constitute a considerable percentage of higher education institutions in Turkey and Northern Cyprus. There are currently 56 active interior design departments to which 4372 new students can be admitted on the basis of their university entrance examination or special aptitude test scores. ${ }^{4,5}$ It is noteworthy that the last two and a half decades have witnessed a dramatic increase in the number of interior design departments. While there were only four (Hacettepe, İhsan Doğramacı Bilkent, Marmara and Mimar Sinan Güzel Sanatlar) universities providing interior design education until 1990, the number of these institutions rose by almost 700 per cent and reached 31 in $2010 .{ }^{6}$ Given that only 12 of the current 56 institutions containing an interior design department are state universities, ${ }^{4}$ it is possible to state that there has been a sharp rise in the number of foundation universities.

Acknowledging the current number of the departments and the upward trend in the last two and a half decades casts doubts on the quality of interior design education in general and lighting design education in particular. Regarding the latter, there is circumstantial evidence of treating lighting design as a subsidiary subject throughout the pattern of interior design education. While it is clear from the most recent technical report of the "Commission Internationale de L'éclairage" (CIE) on lighting design edu-

\footnotetext{
1 Livingston, 2014.

2 Boyce, 2014.
}

5 ÖSYM, 2016b.

6 Adıgüzel, 2011. cation that a teaching period of 21-60 hours only enables the fundamentals of light and lighting to be understood, ${ }^{7}$ in the only study conducted for evaluating the status of lighting design in interior design education in Turkey, Saraf ${ }^{8}$ observed that 15 out of 37 departments did not offer any courses in lighting design for undergraduate and graduate interior design students.

In the light of the above-mentioned findings, it is imperative to understand if our current approach to lighting design education is erroneous and needs to be reconsidered. It must, therefore, be asked whether or not the use of light as a design element is not given the status accorded to many other subjects in undergraduate and graduate interior design education. In an attempt to give an answer to this question and contribute to our limited knowledge about the subject, a study was carried out by thoroughly investigating the educational programs of all 56 interior design departments in both Turkey and Northern Cyprus and administering a questionnaire to department chairs. In this paper, the results of this study are presented.

\section{Methodology}

The study was conducted in two subsequent phases. In the first phase, relevant information about undergraduate and graduate courses in lighting design was gathered by administering the "Course Information Form" (CIF) to the chairs of all interior design departments in Turkey and Northern Cyprus via e-mail and accessing departmental Web sites. In the second phase, the chairs who had filled in and returned the form were contacted again and asked to comment on the approach that they adopted to lighting design education by means of the "Instructor Questionnaire" (IQ).

The CIF, which had been developed by the authors for this study, was administered in November 2015 in order to obtain the following information on the courses: a) course name; b) course code; c) course content; d) course objective(s); e) course level (undergraduate or graduate); f) course type (compulsory or elective); g) course semester; h) weekly course hours; i) course credits (national and ECTS) and j) course lecturer(s). In January 2016, a reminder was sent out to non-respondents. For those who failed to complete and send back the form within two months, no further reminder was emailed. In order to compensate for the missing information, departmental Web sites were accessed in March 2016.

In March 2016, the IQ, which had been developed to enquire about the perceived quality of lighting design education, was also sent out electronically to 17 respondents. The questionnaire consisted of a five-point Likerttype scale for indicating the degree of satisfaction derived

\footnotetext{
7 CIE, 1992. 8 Saraf, 2013.
} 
Table 1. Numbers of undergraduate and graduate programs offering lighting design and related courses in state and foundation universities

\begin{tabular}{lccc}
\hline & $\begin{array}{c}\text { State } \\
\text { University }\end{array}$ & $\begin{array}{c}\text { Foundation } \\
\text { University }\end{array}$ & Total \\
\hline Undergraduate & 12 & 35 & 47 \\
Graduate & 3 & 12 & 15 \\
\hline
\end{tabular}

from the existing departmental courses in lighting design and six open-ended questions in order to understand the reason(s) for satisfaction or dissatisfaction and the extent to which interior design students were given the opportunity of gaining hands-on experience in lighting design and solicit for the respondents' opinions about how to improve those courses.

\section{Results}

\section{Phase 1}

Lighting design and other related courses are included in 47 out of 56 undergraduate programs, and they are offered by 12 state and 35 foundation universities. In only 15 graduate programs, these courses are offered by three state and 12 foundation universities (Table 1).

The above-mentioned undergraduate programs are incorporated within the faculties of "architecture," "architecture and design," "architecture, design and fine arts," "arts and design," "arts, design and architecture," "engineering and architecture," "engineering and natural sciences," "fine arts," "fine arts and architecture," "fine arts and design" and "fine arts, design and architecture." The courses related to lighting design are mainly offered within the faculties of "architecture" and "architecture and design" as it is shown in Table 2.

In addition to the undergraduate programs, only 15 interior design programs appear to offer graduate level courses related to lighting design, and they are mainly present in the graduate schools of "natural and applied sciences" (Table 3). The nature of the courses in both undergraduate and graduate levels are given in the following sections in detail.

Data gathered from all interior design programs show that the undergraduate and graduate courses related to lighting design can be classified into two major types. The first one is a group of courses providing general information about and mainly introducing all subjects in building physics, such as acoustics, HVAC, fire precautions and lighting design. The other one is a specific group of courses on lighting design only, dealing with the basics of light and vision, natural and artificial lighting design principles and applications and the new technologies in the field. The common issue for the undergraduate building physics and lighting design courses is the absence of pre-requisites. The same problem was also identified for the courses offered for graduate interior design students.

Data in Table 4 shows that 16 undergraduate programs have only building physics courses and that 16 of those have only lighting design courses. It is also noteworthy that only 15 undergraduate programs chiefly in foundation universities offer both course types (Table 4). For the graduate programs, data presents a concentration of programs offering only lighting design courses (Table 5).

The collected data was analyzed to find out the con-

Table 2. Names and Numbers of faculties offering undergraduate lighting design and related courses

\begin{tabular}{|c|c|c|c|c|c|c|c|c|c|c|}
\hline 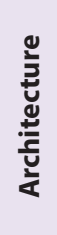 & 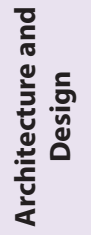 & 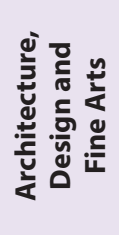 & 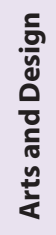 & 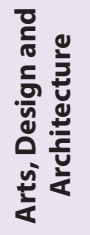 & 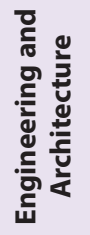 & 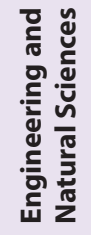 & 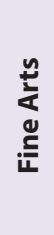 & 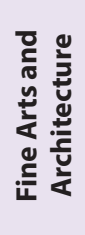 & 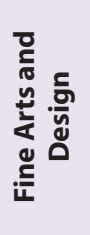 & 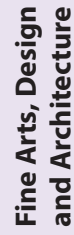 \\
\hline 10 & 9 & 1 & 3 & 1 & 5 & 1 & 7 & 2 & 3 & 5 \\
\hline
\end{tabular}

Table 3. Names and Numbers of graduate schools offering lighting design and related courses

Graduate school of Education and Research

1
Graduate School of Economy and Social Sciences
Graduate School of Natural and Applied Sciences
Graduate School of Social Sciences
11
2 
Table 4. Numbers of programs offering undergraduate building physics and lighting design courses in state and foundation universities

\begin{tabular}{lccc}
\hline & Building Physics & Lighting Design & Both Building Physics and Lighting Design \\
\hline State University & 2 & 7 & 3 \\
Foundation University & 14 & 9 & 12 \\
Total & 16 & 16 & 15 \\
\hline
\end{tabular}

Table 5. Numbers of programs offering graduate building physics and lighting design courses in state and foundation universities

\begin{tabular}{lccc}
\hline & Building Physics & Lighting Design & Both Building Physics and Lighting Design \\
\hline State University & 1 & 2 & 0 \\
Foundation University & 1 & 10 & 1 \\
Total & 2 & 12 & 1 \\
\hline
\end{tabular}

Table 6. Numbers of undergraduate compulsory and elective courses in building physics and lighting design concerning ECTS credits

\begin{tabular}{llccccccc}
\hline & & 2 ECTS & 3 ECTS & 4 ECTS & 5 ECTS & >5 ECTS & Unknown ECTS $^{*}$ & Total $^{*}$ \\
\hline \multirow{2}{*}{ Building Physics } & Compulsory & 3 & 5 & 16 & 6 & 1 & 0 & 31 \\
& Elective & 0 & 0 & 3 & 0 & 0 & 4 \\
\multirow{2}{*}{ Lighting Design } & Compulsory & 0 & 4 & 8 & 0 & 1 & 3 \\
& Elective & 4 & 9 & 7 & 3 & 0 & 3 \\
\hline
\end{tabular}

*For seven of the undergraduate courses, ECTS credits could not be obtained.

Table 7. Numbers of graduate compulsory and elective courses in building physics and lighting design concerning ECTS credits

\begin{tabular}{llccccccc}
\hline & & 4 ECTS & 5 ECTS & 6 ECTS & 7 ECTS & > 7 ECTS & Unknown ECTS & Total \\
\hline \multirow{2}{*}{ Building Physics } & Compulsory & 0 & 1 & 0 & 0 & 0 & 0 & 1 \\
& Elective & 0 & 0 & 1 & 0 & 0 & 1 \\
\multirow{2}{*}{ Lighting Design } & Compulsory & 0 & 0 & 0 & 0 & 0 & 0 & 3 \\
& Elective & 4 & 0 & 6 & 1 & 5 & 19 \\
\hline
\end{tabular}

*For four of the graduate courses, ECTS credits could not be obtained.

centration of undergraduate lighting design and related courses with respect to their status (compulsory or elective) and ECTS credits. It is apparent from Table 6 that they are mainly offered as four-credit compulsory building physics courses and that only 16 compulsory lighting design courses are taken by the undergraduate students. It is striking that, in the graduate interior design programs, no compulsory lighting design courses are available (Table 7). Mainly six-credit elective lighting courses can be taken by the graduate students.

Weekly theoretical and practical hours of the building physics and lighting design courses were also investigated in the analysis. It was found that the length of most un- dergraduate courses is not more than two or three hours per week (Table 8). Only 17, or about 23 per cent, of the courses have a length of more than three hours per week. It is also evident from Table 8 that 19, or more than half, of all building physics courses and the vast majority of the lighting design courses are theoretical - in other words, they include limited or no time for students to practically use their theoretical knowledge about the subject. For the graduate courses, the collected data presents a concentration of three-hour elective courses in lighting design (Table 9). It can be seen from Table 9 that, except one of the building physics courses, almost all graduate courses are theoretical in nature. 
Table 8. Numbers of undergraduate compulsory and elective courses in building physics and lighting design concerning theoretical and practical course hours

\begin{tabular}{|c|c|c|c|c|c|c|c|c|}
\hline & & & 1 hour & 2 hours & 3 hours & 4 hours & 8 hours & Total* \\
\hline \multirow[t]{4}{*}{ Building Physics } & Compulsory & Theory & 0 & 5 & 9 & 2 & 0 & 16 \\
\hline & & Theory + Practice & 0 & 1 & 2 & 10 & 1 & 14 \\
\hline & Elective & Theory & 1 & 1 & 1 & 0 & 0 & 3 \\
\hline & & Theory + Practice & 0 & 0 & 1 & 0 & 0 & 1 \\
\hline \multirow[t]{4}{*}{ Lighting Design } & Compulsory & Theory & 0 & 3 & 7 & 1 & 0 & 11 \\
\hline & & Theory + Practice & 0 & 0 & 2 & 3 & 0 & 5 \\
\hline & Elective & Theory & 0 & 16 & 6 & 0 & 0 & 22 \\
\hline & & Theory + Practice & 0 & 0 & 3 & 0 & 0 & 3 \\
\hline
\end{tabular}

*For one of the compulsory building physics and elective lighting design courses, information about course hours could not be obtained.

Table 9. Numbers of graduate compulsory and elective courses in building physics and lighting design concerning theoretical and practical course hours

\begin{tabular}{|c|c|c|c|c|c|c|}
\hline & & & 2 hours & 3 hours & 4 hours & Total $^{*}$ \\
\hline \multirow[t]{4}{*}{ Building Physics } & Compulsory & Theory & 0 & 0 & 0 & 0 \\
\hline & & Theory + Practice & 0 & 0 & 1 & 1 \\
\hline & Elective & Theory & 1 & 1 & 0 & 2 \\
\hline & & Theory + Practice & 0 & 0 & 0 & 0 \\
\hline \multirow[t]{4}{*}{ Lighting Design } & Compulsory & Theory & 0 & 0 & 0 & 0 \\
\hline & & Theory + Practice & 0 & 0 & 0 & 0 \\
\hline & Elective & Theory & 5 & 12 & 0 & 17 \\
\hline & & Theory + Practice & 0 & 0 & 0 & 0 \\
\hline
\end{tabular}

*For two of the elective lighting design courses, information about course hours could not be obtained.

\section{Phase 2}

The IQ was completed by 17 respondents, of whom 11 expressed their satisfaction. While two of the remaining six respondents were indecisive, four of them were dissatisfied. The numbers of the courses offered in the undergraduate and graduate programs for which either satisfaction and no satisfaction was reported are given in Table 10 and 11. Although the average numbers of both undergraduate and graduate lighting design courses are lower in the satisfactory programs (Table 10 and 11), the respondents for

Table 10. Numbers and averages of the taught courses in the satisfactory programs

\begin{tabular}{lcc}
\hline & Building Physics & Lighting Design \\
\hline Undergraduate & & \\
$\quad \mathrm{n}$ & 8 & 10 \\
$\quad$ Average $(\mathrm{n} \div 11)$ & 0.73 & 0.91 \\
Graduate & & \\
$\mathrm{n}$ & 1 & 3 \\
$\quad$ Average $(\mathrm{n} \div 4)$ & 0.25 & 0.75 \\
\hline
\end{tabular}

those programs stated that both the quantity and quality of the available courses are able to foster the acquisition of necessary knowledge of and skills in lighting design. The dissatisfied and indecisive respondents pointed out several problems regarding the lighting design education in their departments. They expressed their complaints about the lack of facilities, having mainly elective courses in the subject, theoretical course content, inadequate course hours, overcrowded classes, little or no cooperation with the industry and experiencing considerable difficulties in
Table 11. Numbers and percentages of the taught courses in the programs for which no satisfaction was reported

\begin{tabular}{lcc}
\hline & Building Physics & Lighting Design \\
\hline $\begin{array}{l}\text { Undergraduate } \\
\mathrm{n}\end{array}$ & 4 & 8 \\
$\quad$ Average $(\mathrm{n} \div 6)$ & 0.67 & 1.33 \\
Graduate & & \\
$\quad \mathrm{n}$ & 0 & 5 \\
$\quad$ Average $(\mathrm{n} \div 3)$ & 0 & 1.67 \\
\hline
\end{tabular}


the organization of visits to successfully completed lighting designs.

Regardless of the level of satisfaction reported, all respondents agreed on the importance of having a laboratory and other facilities at university and, as a direct consequence, gaining hand-on experience and a better insight into lighting design. Despite this general view, it is quite striking that only one of all 17 respondents reported having a lighting laboratory in their institute and that four of those stated the utilization of computer software or technical equipment in their lighting design education. Apart from the availability of the facilities, there is a general consensus among the respondents about the weak or no integration of lighting design and studio courses at the undergraduate level. According to six of the respondents, studio instructors' lack of competency or interest in the field and low level of expectations with respect to the subject might cause this problem. Only four of the remaining respondents believed that students were expected and able to use their knowledge of lighting design in design courses.

\section{Discussion and conclusion}

It has been amply demonstrated that light has profound effects on us. Therefore, it is possible to state that good lighting is essential for a high-quality built environment. This raises the key question of how good lighting can be achieved. It is clear that providing sufficient knowledge about light and its use in interior design education would be a contributing factor. On the basis of the available literature, it is difficult to assess and comment on the quality lighting design education provided by the interior design departments in Turkey and Northern Cyprus. For this reason, a study was undertaken in two subsequent phases in order to update and widen our knowledge about the subject.

In the first phase, information about undergraduate and graduate courses in lighting design was gathered by administering the CIF and accessing departmental Web sites. Our analysis of the collected data revealed that both compulsory and elective courses on the subject constitute only a small fraction of the educational programs of many interior design departments and that the use of light as a design element is not given the status accorded to other subjects. Given the fact that a teaching period of 21-60 hours only enables the fundamentals of light and lighting to be understood, ${ }^{7}$ it would be erroneous, or at least inappropriate, to expect students to highly benefit from brief (two- or three-hour) introductory courses in building physics and lighting design and use light effectively in their designs.

\footnotetext{
${ }^{7} \mathrm{CIE}, 1992$
}

If we accept that our current approach to lighting design education needs to be reconsidered, then it is important to think about what should be done in order to deal with this issue. Our findings from the second phase, in which the perceived quality of lighting design education was identified by means of the $I Q$, give some insight into what course of action should be taken. Given the comments of the respondents on the elusive character of light and theoretical nature of the available courses in interior design programs, one possible way of adopting a better approach and improving lighting design education is to give students the opportunity of gaining hands-on experience. In order to demonstrate the possibilities of using different luminaires and light sources, it would be very useful to construct mock-up rooms and establish laboratories with necessary equipment. ${ }^{7}$ It is both surprising and unfortunate that only one of all 17 respondents reported having a fully equipped laboratory in their institution. In addition, organizing field trips to see real-life design solutions and visit lamp and luminaire factories seems to be of great value to design students and help them to effectively use light as a tangible design element in their design courses. ${ }^{9}$ There is no doubt that the elective status of 74 per cent of the specialized lighting design courses and concerns of the respondents about this issue should be taken seriously. It should be noted here that it is unlikely to increase the number of courses in the existing curricula since the Bologna accreditation process has limited total ECTS credits for one semester to 30 ECTS credits. Given these circumstances, another way would be to change the status of lighting design courses from elective to compulsory. This change is considered to be imperative because it ensures all interior design students to benefit from specialized courses in the subject. Moreover, this may increase the opportunity for integrating lighting design and studio courses.

Despite the fact that light not only enables vision but also has been demonstrated to be instrumental in enhancing our general well-being and, as a direct consequence, quality of life, many interior design schools, regrettably, do not attach great importance to it. Therefore, it is absolutely imperative that we, as educators and policy makers, must take action immediately to address the above-mentioned issues in order to improve our lighting design education and give students the opportunity of understanding and using light better.

\section{Acknowledgements}

We would like to express our gratitude to all department chairs and course instructors for sparing their valuable time and help. The authors also thank the anonymous reviewers for their comments on an earlier version of this paper.

\footnotetext{
${ }^{7} \mathrm{CIE}, 1992 . \quad 9$ Isoardi, 2010.
} 


\section{References}

Adıgüzel, D. (2011) “Türkiye'deki İç Mimarlık Eğitiminde Çevresel Yaklaşım", Basılmamış Yüksek lisans Tezi, Kadir Has Üniversitesi, Sanat ve Tasarım Fakültesi.

CIE. (1992) Technical Report: Lighting Education (1983-1989), Vienna, $\mathrm{CIE}$.

Boyce, P.R. (2014) Human Factors in Lighting 3rd ed., Boca Raton $\mathrm{FL}$, Taylor and Francis.

Isoardi, G. (2010) "Evaluating the Learning Outcomes of an International Field Trip in Postgraduate Lighting Design Courses", Journal of Learning Design, Sayı 3, s. 37-44.

Leech J.A., Nelson, W.C., Burnett, R.T., Aaron, S. \& Raizenne M.E. (2002) "It Is About Time: A Comparison of Canadian and
American Time-Activity Patterns", Journal of Exposure Analysis and Environmental Epidemiology, Sayı 12, s. 427-432.

Livingston, J. (2014) Designing with Light: The Art, Science and Practice of Architectural Lighting Design, Hoboken NJ, John Wiley \& Sons.

Saraf, M. (2013) “Türkiye'de İç Mimarlık Eğitiminde Aydınlatmanın Yeri ve Önemi", VII. Ulusal Aydınlatma Sempozyumu, 21-22 Kasım 2013, İzmir.

Internet Sources

http://dokuman.osym.gov.tr/pdfdokuman/2016/LYS/Yerlestirme_Tablo-4_min/Max_Lisans10082016.pdf

http://dokuman.osym.gov.tr/pdfdokuman/2016/LYS/TERCIH/ OSYSKONTENJANKILAVUZU01082016.pdf [Erişim tarihi 01 Kasım 2016] 